\title{
Anatomy of Shuck Abscission in 'Desirable' Pecan
}

\author{
Darrell Sparks \\ Department of Horticulture, University of Georgia, Athens, GA 30602
}

I.E. Yates

Russell Research Center, Agricultural Research Service, U.S. Department of Agriculture, Athens, GA 30605

\begin{abstract}
Additional index words. Carya illinoinensis, dehiscence, fruit maturity, markings, microscopy, morphology, shell, suture, vascular system

Abstract. Cellular changes associated with shuck dehiscence and markings deposited on pecan [Carya illinoinensis (Wangenh.) C. Koch] shells were examined by scanning electron and light microscopy. Fruit were sampled at three stages of maturity: 1) shuck and shell fused, 2) sutures separated (shuck opening), and 3) vascular system separated from shuck. Shuck dehiscence involved temporally regulated abscission events with shuck-shell, then shuck-suture, and finally shuck-vascular system separation. Abscission events occurred in a tissue zone common to and continuous among all three separation sites, even though segregated in time. Also, similar cell types and cellular changes were common to the three events. Thus, temporal segregation of abscission events was not due to differences in either tissue type or cellular modifications, but to maturation rate. Structures to become shell markings were single globules filling cells of the shuck inner tissue zone before shuck-shell separation. These globules were deposited on the shell at shuck-shell separation and were morphologically similar to deposits stuck to the dorsal shuck surface. Globules were partitioned differentially between the shuck and shell during shuck-shell separation. Thus, the inner zone of the shuck is an important tissue in pecan nut maturation; it functions as the site for dehiscence and provides markers for cultivar identification.
\end{abstract}

The pecan fruit is a drupelike nut with a floral envelope or shuck enclosing the ovary (Lawrence, 1965), the wall of which matures as the shell (Woodroof and Woodroof, 1927). Some authors have interpreted the shuck as having evolved from sepals (Bailey, 1924; Shuhart, 1932; Woodroof and Woodroof, 1927). Others have argued that the shuck has been derived from a bract, two bracteoles and a sepal (DeCandolle, 1862; Eichler, 1878; Manning, 1940). Regardless of origin, the shuck is divided into four quarters that are bound together along sutures.

The pecan shuck has an important role in the development of the commercially important product of the pecan tree, the kernel. Nutrients required for the development of the kernel and shell are transported through the shuck (Shuhart, 1931). The importance of the vascular system has prompted several investigators to track the course of veins through the shuck, particularly through the developing fruit (Calcote et al., 1984; Nast, 1935; Shuhart, 1931). Major veins extend the length of the shuckjust beneath the ventral surface to the distal end of the fruit, then turn to descend the length of the fruit just beneath the dorsal surface, and finally enter the base of the ovary wall. Due to the turn of the veins at the distal end, the phloem and xylem are reversed relative to each other on the dorsal and ventral side of the shuck. Thus, the organization of the veins has been referred to as the inner (dorsal) and outer (ventral) vascular system (Calcote et al., 1984), although the system is continuous. Morphologically, the surface of the shuck next to the shell of the nut is the dorsal surface and the outer shuck surface is the ventral surface.

In spite of the investigation focused on the vascular system, only superficial observations have been made of other shuck tissues, especially during shuck dehiscence. Woodroof and Woodroof (1927) recounted that, at the onset of fruit maturity, the shuck begins to lose moisture and change color beginning at the

Received for publication 30 Jan. 1995. Accepted for publication 18 May 1995. We appreciate the technical assistance of Gloria Belvan, Donnie Maxey, and Joyce Lambert. The cost of publishing this paper was defrayed in part by the payment of page charges. Under postal regulations, this paper therefore must be hereby marked advertisement solely to indicate this fact.

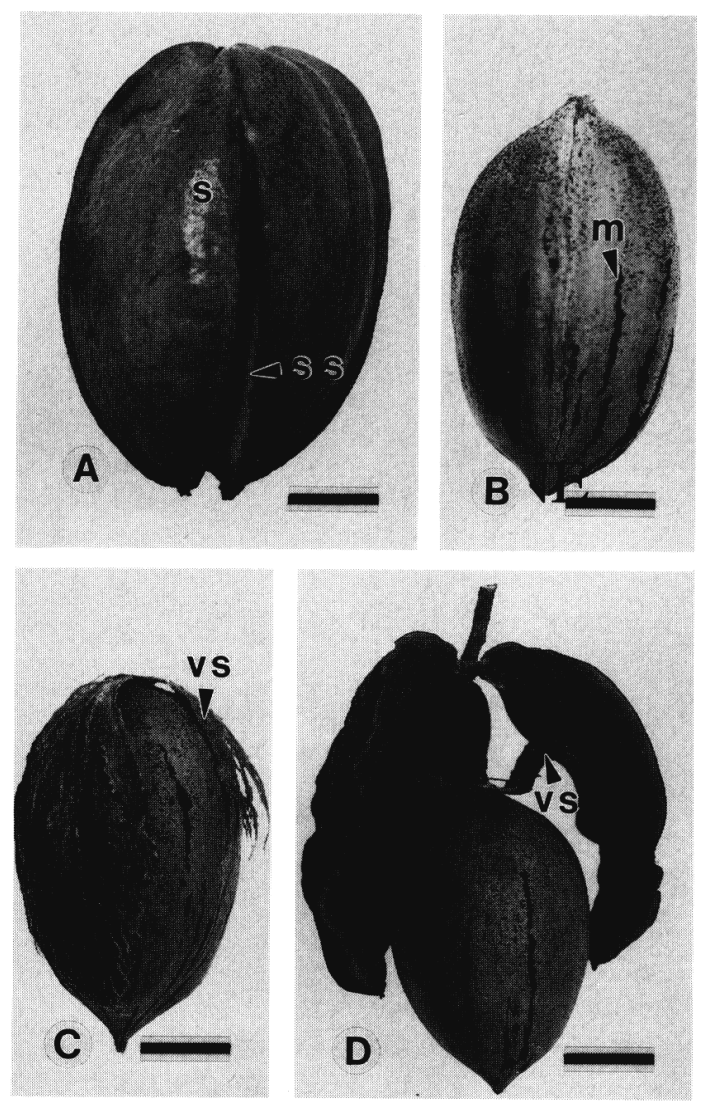

Fig. 1. Shuck sutures split with slight pressure to fruit (A), and shell markings had developed (B) at initial shuck opening. The second sample was collected at this time. The nut with attendant vascular system could be manually separated from the shuck at the third sampling $(\mathbf{C})$. Mature nuts on the tree were attached to the dried shuck by the vascular system (D). Fruit in $\mathbf{D}$ had two shuck quarters removed to expose vascular system attachment to shuck and shell. Abbreviations: $\mathrm{s}=$ shuck, $\mathrm{ss}=$ shuck suture, $\mathrm{m}=$ shell markings, $\mathrm{vs}=$ vascular strands. Bars $=12$ mm (A-D). 
apical. These changes are followed by the shuck's dividing into four segments and separating from the-shell. Our preliminary field observations indicated that shuck abscission involved a sequential process that could be divided into finite steps that did not follow the sequences of suture separation and shuck-shell separation alluded to by Woodroof and Woodroof (1927). Shuhart (1932) parenthetically noted that the immature pecan fruit had a line of thin-walled parenchyma cells continuous between the sutures and surrounding the ovulary wall. However, no analyses of this zone in the abscission process were undertaken.

Fruit maturity involves shuck dehiscence and development of shell markings (Woodroof and Woodroof, 1927). Markings ap- pear as dots and irregular stripes. Stripes are abundant on the apical end of the nut and gradually thin out until only dots appear on the basal end of the nut. The relative density and pattern of stripes and dots is a characteristic used to identify cultivars (Sparks, 1992). Markings appear just as the shuck begins to abscise from the shell and initially are very faint and pinkish. Once distinguishable macroscopically, the markings develop rapidly. Concomitantly, the color of the markings changes from pink to shades of red to black; the exact shade is a cultivar characteristic. Markings are easily removed from the shell by rubbing or brushing and are often lost during harvesting. Woodroof and Woodroof (1927) noted that color markings of the pecan shell are a result of a deposit of the
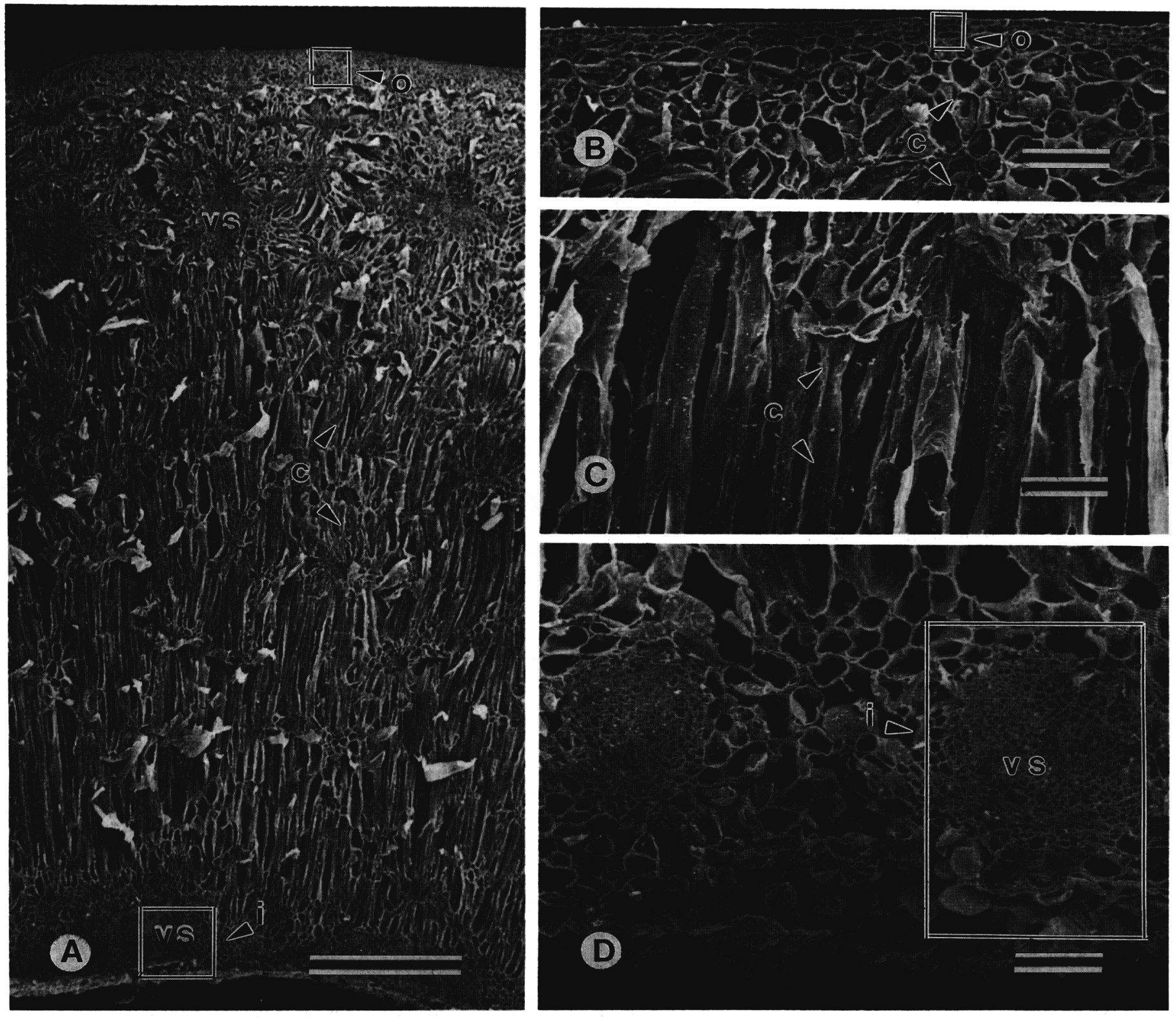

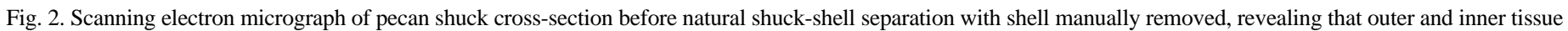
zones were narrow and the central tissue zone was wide, with vascular strands apparent in the central and inner tissue zones (A). The outer tissue zone contained about four layers of rectangular cells $(\mathbf{B})$; the central tissue zone contained many layers of elongated cells (A and $\mathbf{C})$; and the inner tissue zone contained about 10 layers of rounded cells (D). Box tops and bottoms define limits of indicated tissue zones. Abbreviations: $\mathrm{o}=$ outer tissue zone, $\mathrm{c}=$ central tissue zone, $\mathrm{i}=$ inner tissue zone, vs $=$ vascular strand. Bars $=1.0 \mathrm{~mm}(\mathbf{A})$ and $0.1 \mathrm{~mm}(\mathbf{B}-\mathbf{D})$. 
separated cells of an abscission layer formed around the vascular bundles. However, no further details were given about the position of this layer or timing of abscission.

Three distinctive tissue zones identified as the outer, central, and inner zone make up the shuck (Sparks-et al., 1995). The inner zone next to the shell consists of about 10 layers of thin-walled, parenchymatous cells. This zone coincides with the cells described by Woodroof and Woodroof (1927) as embedding the dorsal vascular system. The objective of this study was to examine the morphology of shuck abscission in pecan. We focused on the role of the inner shuck tissue zone in the separation of the shuck from the shell, the separation of the shuck sectors at the suture, and the separation of the vascular system from the shuck and in the deposition of markings on the shell. Understanding the morphology of shuck abscission is prerequisite to studies on the physiology of shuck opening. Advancing shuck dehiscence is a major concern in early pecan harvesting technology.

\section{$M$ aterials and $M$ ethods}

Fruit samples. Six 'Desirable' fruit from different trees were sampled at three stages of maturity. Shuck and shell were fused at the first sampling. The second sample was taken at initial shuck opening (Fig. 1A). The markings were well developed on the shell (Fig. 1B) at the second sampling. The third sample was collected later and after the vascular bundle had separated from the shuck to the point it could be manually removed from the shuck (Fig. 1C). The shuck was turgid at this stage and had not begun to discolor and dry as occurs with full nut maturity (Fig. 1D). The first sampling was made to study shuck anatomy before the onset of abscission. The second and third samplings were made to follow the progression of abscission.

Shucks from all fruit maturity stages were dissected for examination by scanning electron microscopy (SEM). Sections were taken at the midpoint of the fruit perpendicular to the long axis of
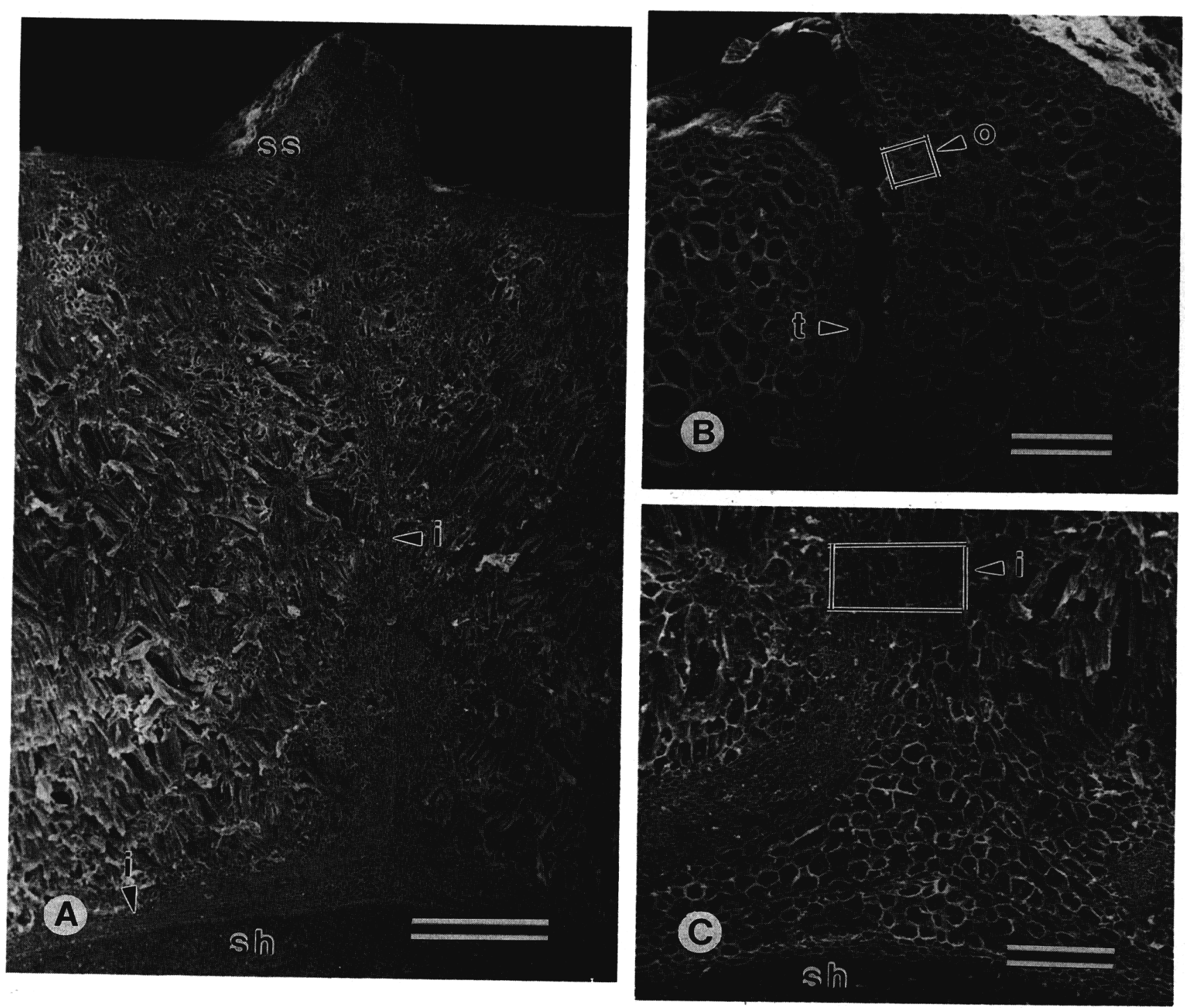

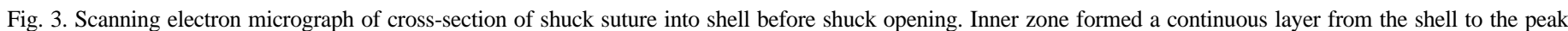

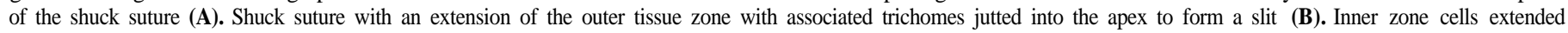

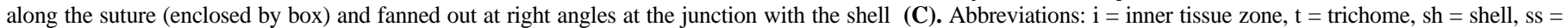
shuck suture, $\mathrm{o}=$ outer tissue zone. Bars = $1.0 \mathrm{~mm}(\mathbf{A}), 0.1 \mathrm{~mm}(\mathbf{B})$, and $0.24 \mathrm{~mm}(\mathbf{C})$. 
the fruit and thus were cross-sections of the vascular system. Color markings were examined for nuts only from the second sampling date. Sections of the shell surface that included areas with and without markings were prepared for SEM examination. Corresponding areas on the shuck were examined for comparison.

Microscopy. Tissues prepared for SEM were fixed overnight at $4 \mathrm{C}$ in $4 \%$ glutaraldehyde in $0.1 \mathrm{~m}$ sodium cacodylate buffer, $\mathrm{pH}$ 7.2 , and dehydrated in an ethanol series $(30 \mathrm{~min}$ in each of $50 \%$, $70 \%, 100 \%)$. Samples were then critical-point dried with $\mathrm{CO}_{2}$, mounted on Al stubs, coated with gold-palladium, and examined at $10 \mathrm{kV}$ with a SEM (model 505; Philips Electronic Instruments Co., Mahwah, N.J.). Samples for light microscopy (LM) were prefixed overnight at $4 \mathrm{C}$ with $4 \%$ glutaraldehyde and postfixed for $1 \mathrm{~h}$ in an ice bath with $1 \%$ osmium tetroxide in 0.1 M sodium cacodylate buffer, $\mathrm{pH}$ 7.2. After dehydration in an ethanol series as described above for SEM, samples for LM were infiltrated and embedded in resin (Spurr, 1969). Thick 0.5- $\mu$ m sections were cut using an ultramicrotome (model Ultracut E; Reichert-Jung, Vienna, Austria), stained with a mixture of $1 \%$ azure II and $1 \%$ sodium borate $(1: 1, \mathrm{v} / \mathrm{v})$ by applying gentle heat to the glass slides, and examined with a microscope (Leitz Dialux 22 EB; LEICA, Wetzlar, Germany).

\section{Results and Discussion}

Macroscopic examination of intact and dissected pecan fruit before and during shuck dehiscence demonstrated that shuck abscission can be regarded as a three-step sequence, with each step segregated in time from 2 to several days. During the first step, the shuck separated from the shell and the shell markings developed.
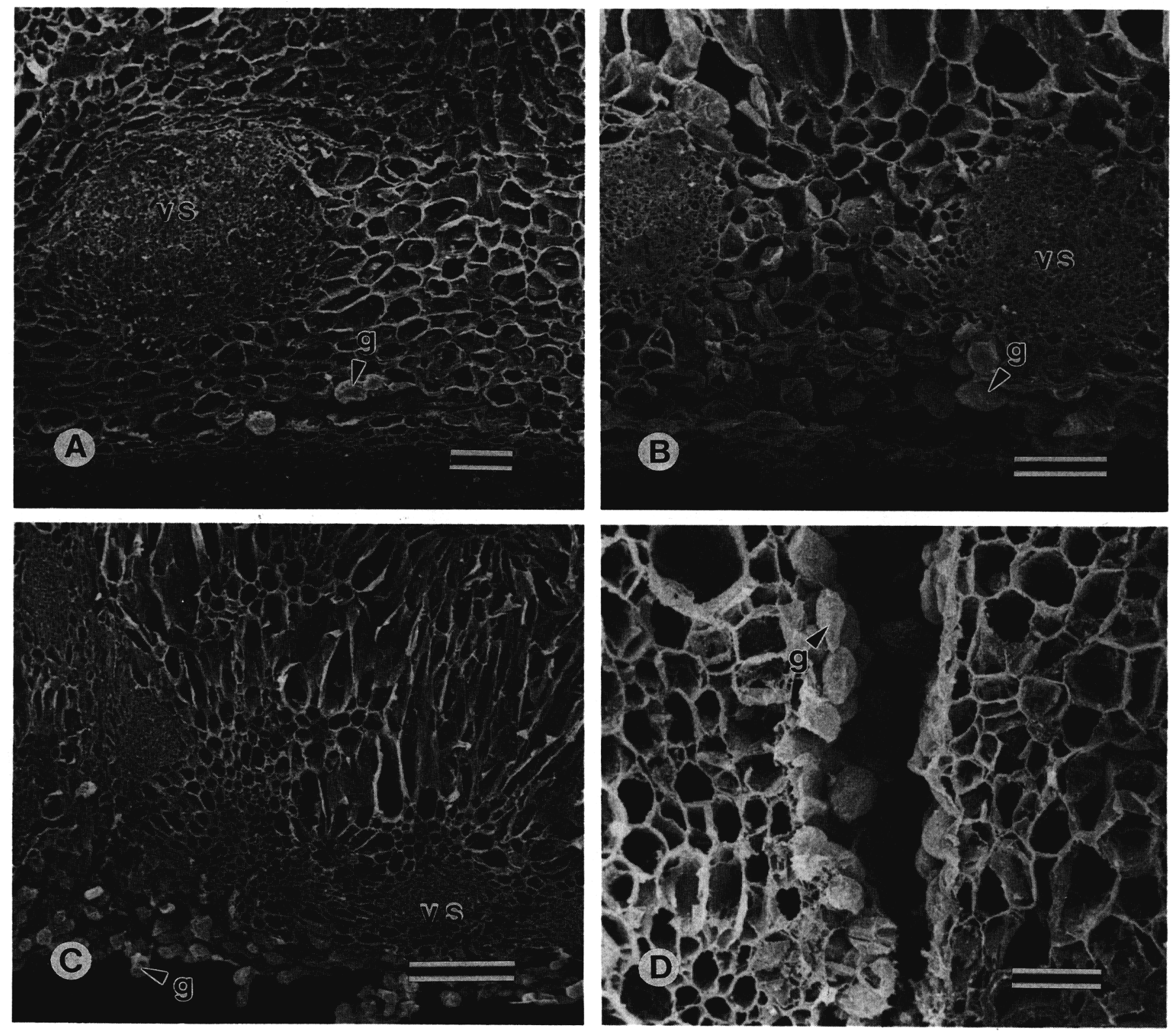

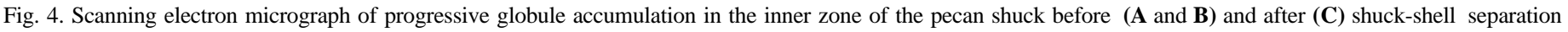
and after shuck-suture separation (D). Abbreviations: $\mathrm{g}=$ globule, vs = vascular strand. Bars = $0.1 \mathrm{~mm}(\mathbf{A}$ and B $), 0.25 \mathrm{~mm}(\mathbf{C})$, and $0.074 \mathrm{~mm}(\mathbf{D})$.

J. Amer. Soc. Hort. Sci. 120(5):790-797. 1995. 
Both processes began at the distal end of the fruit. The second step occurred shortly afterwards as the shuck sutures began to abscise naturally from the distal end, separating the shuck into four quarters. The fruit is considered bpen when the sutures have abscised. The third step in the abscission process occurred when the vascular system partially detached from the dorsal surface of the shuck. Unlike the first two steps, abscission of the vascular system initiated at the proximal end of the fruit (Fig. 1D). After these events, the shuck began to dry and gradually shriveled and blackened. The nut remained loosely attached at the base to the vascular system until falling naturally or shaken free by harvesting. Separation of the shell from the shuck, of the shuck quarters, and of the vascular system suggests three abscission tissues: one between the shuck and the shell, one between the shuck quarters, and one between the vascular system and the shuck.

The shuck had outer, central, and inner tissue zones that were distinguished by cell size and shape (Fig. 2A) as previously reported (Sparks et al., 1995). The outer zone consisted of four layers of small, rectangular cells whose long axes were parallel to the surface of the fruit (Fig. $2 \mathrm{~A}$ and B). The central zone comprised most of the shuck and began about $0.1 \mathrm{~mm}$ from the surface (Fig. $2 \mathrm{~A}$ and $\mathrm{C}$ ). Cell size increased and shape became more elongated perpendicular to the shuck surface with each progressive layer toward the inner zone. The third and inner tissue zone of the shuck was made up of about 10 layers of small, rounded, parenchyma cells (Fig. 2 A and D). Major veins were evident in the central zone
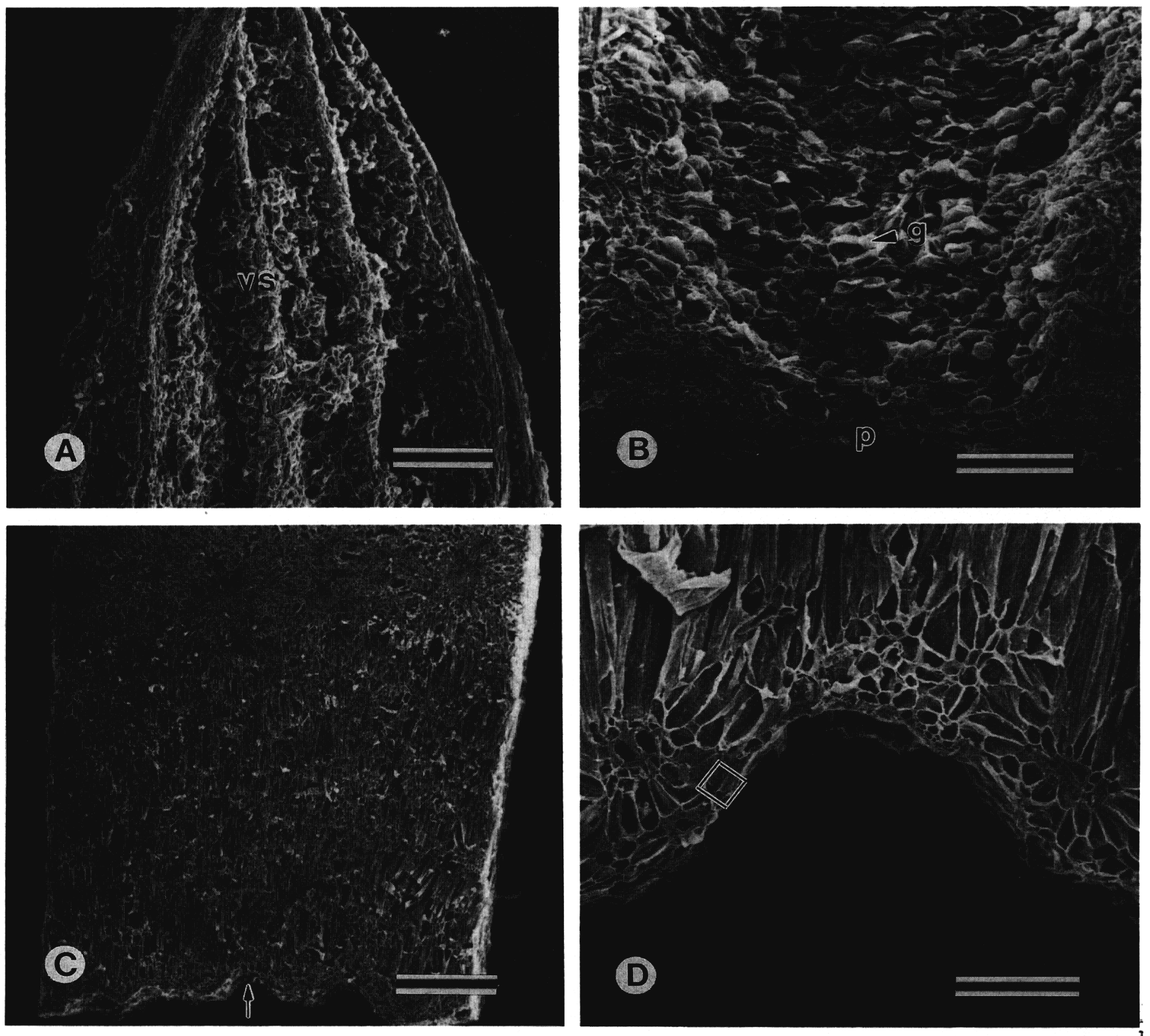

Fig. 5. Scanning electron micrograph of shuck-vascular system separation. Surface view of intact vascular system separated from.the shuck (A), cross-section of vascular strands connected by a thin layer of parenchymatous cells with globules on the surface (B), cross-section of shuck after vascular system removal with sharp indentations at areas previously occupied by vascular strands (arrow) (C), and a layer of inner zone cells remaining attached to the central zone of the shuck (D). Abbreviations: vs = vascular strand, $\mathrm{p}=$ parenchymatous cells, $\mathrm{g}=$ globules, box $=$ inner zone. Bars $=0.5 \mathrm{~mm}(\mathbf{A}), 0.25 \mathrm{~mm}(\mathbf{B})$; $1.0 \mathrm{~mm}(\mathbf{C})$, and $0.25 \mathrm{~mm}(\mathbf{D})$. 

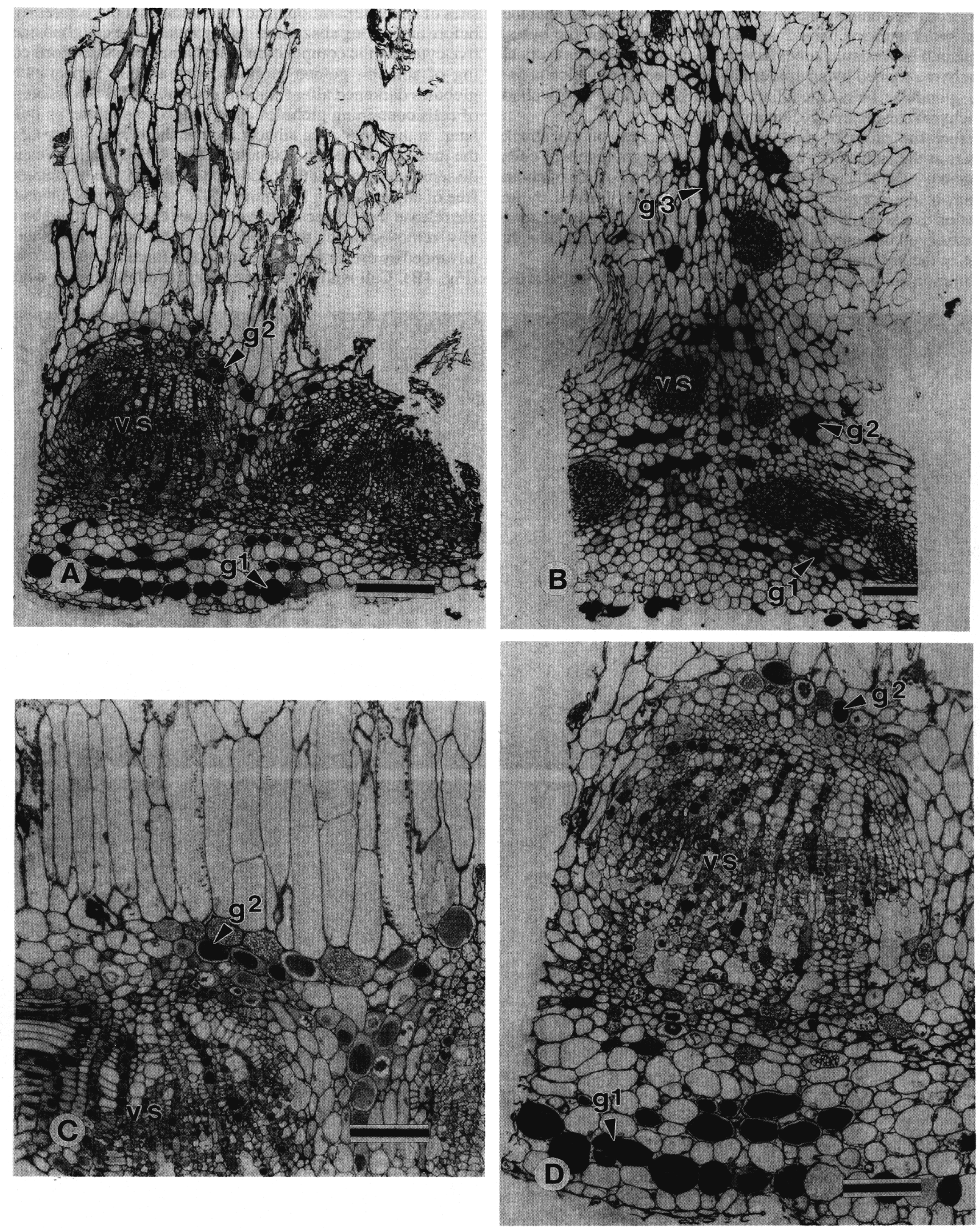

Fig. 6. Light micrograph of globules in abscission sites for shuck-shell and shuck-vascular system (A) and shuck-suture (B) separation. Globules in the shuck-vascular system abscission site were surrounded by cell walls (C); whereas, globules adjacent to shell appeared to have no cell walls (D). Abbreviations: g1 = globules at shuck-shell abscission site, g2 = globules at shuck-vascular system abscission site, $\mathrm{g} 3=$ globules at shuck-suture abscission site, vs $=$ vascular strand. Bars $=0.1 \mathrm{~mm} \quad(\mathbf{A}$ to $\mathbf{D})$. 
just beneath the ventral shuck surface and in the inner zone near the dorsal shuck surface (Fig. 2 A and D). The cells of the outer, central, and inner tissue zones have been characterized as cortical parenchyma topped by an epidermal cell layer from which arose many glandular hairs, medullary parenchyma, and thin-walled parenchyma, respectively (Shuhart, 1932).

Before the onset of dehiscence, the juncture of the shuck quarters at the suture was bordered by about eight layers of cells that were continuous with the inner zone (Fig. 3A). A slit of about $0.5 \mathrm{~mm}$ in the apex of the suture (Fig. 3B) was formed by an extension of the outer zone with associated trichomes. Inner zone cells extended in a band along the suture and radiated out at right angles at the junction with the shell (Fig. 3C).

Common morphological cellular events could be detected at the
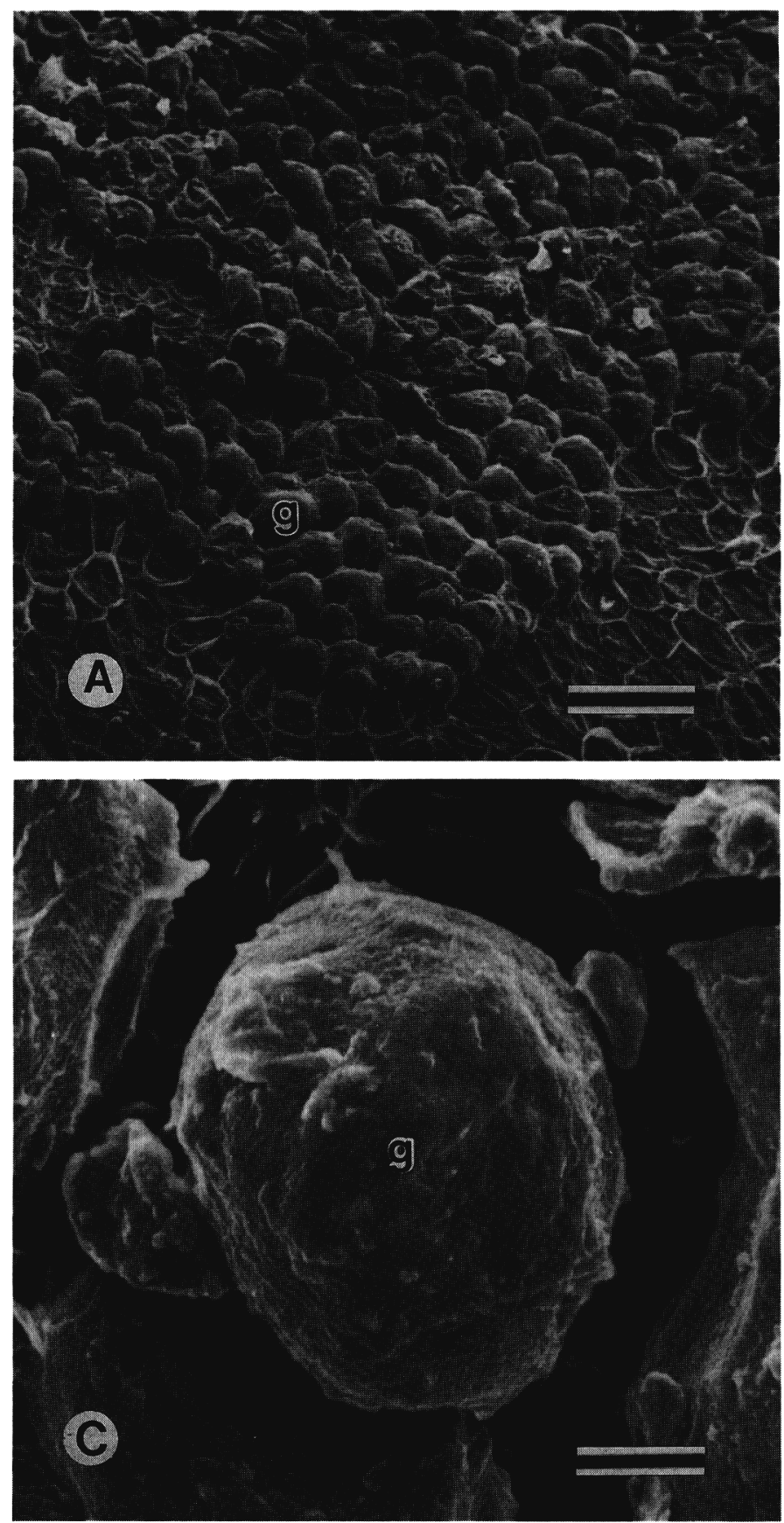

sites of shuck separation from the shell and at the sutures by SEM before and during abscission. Many inner-zone cells had a distinctive cytoplasmic composition in unstained cross-sections consisting of smooth, golden globules with an oily appearance. The globules darkened after fixation or staining of shuck tissue. Walls of cells containing globules appeared to deteriorate, as indicated later, in the inner zone adjacent to the shell (Fig. $4 \mathrm{~A}$ to $\mathrm{C}$ ) and at the juncture of the shuck quarters (Fig. 4D). The globules neither disseminated nor lost their rounded shape in spite of their existing free of any enclosing structures. Cell wall deterioration and globule release were detectable even before the shuck could be manually removed from the shell (Fig. 4A) and were even more advanced by the time the shuck could be forced apart from the shell (Fig. 4B). Cell wall deterioration and globule release were very
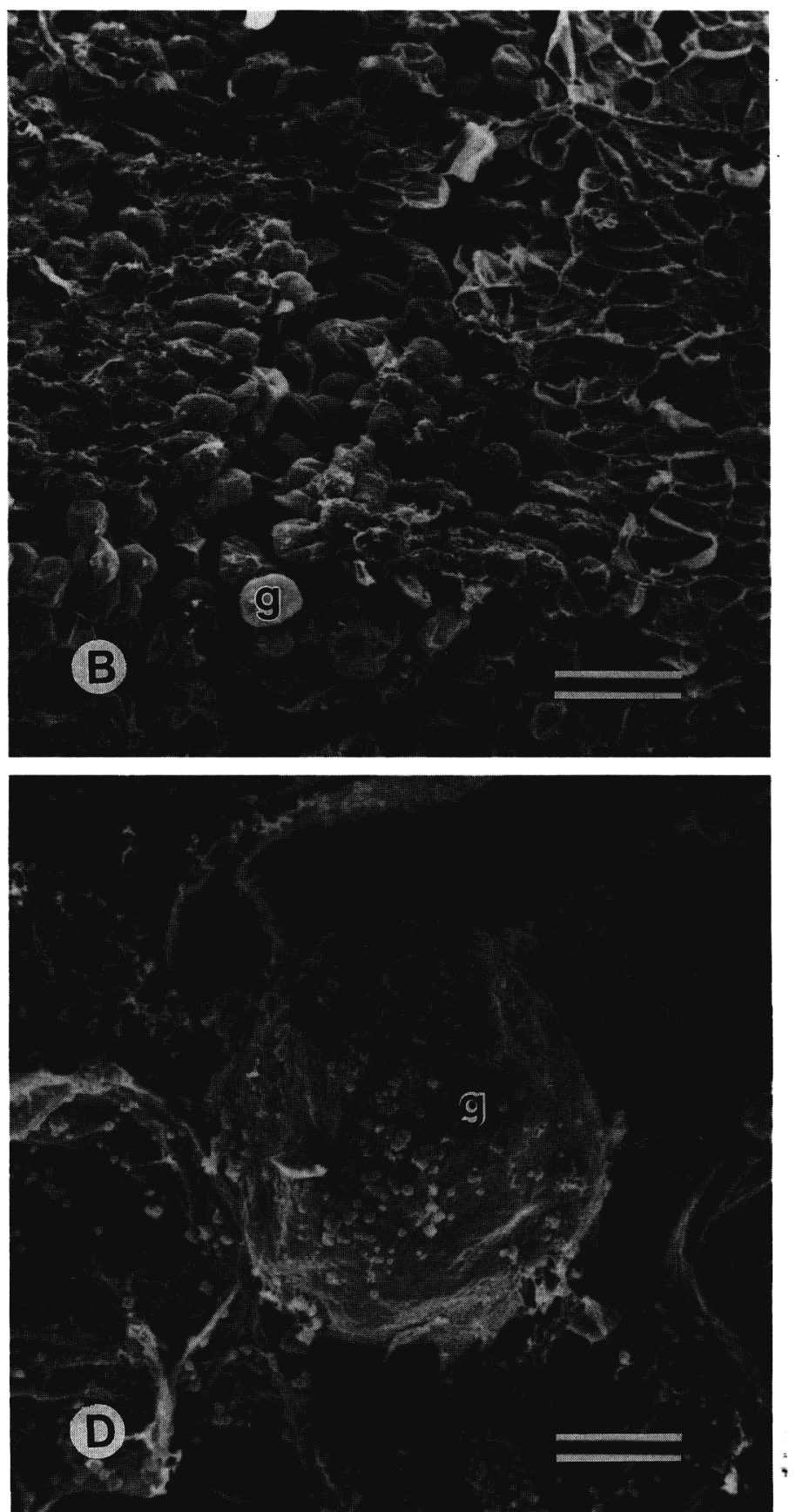

Fig. 7. Scanning electron micrograph of shell (A and $\mathbf{C})$ and shuck (B and $\mathbf{D})$ surface. Globules formed shell markings (A) and were present on shuck surface adjacent to shell (B). The shape and appearance of globules on shell (C) and shuck (D) were similar. Abbreviations: $g=$ globules. Bars $=0.1 \mathrm{~mm}(\mathbf{A}$ and $\mathbf{B})$ and $10 \mu \mathrm{m}(\mathbf{C}$ and $\mathbf{D})$. 
conspicuous once natural shuck-shell (Fig. 4C) and suture (Fig. 4D) separation had occurred.

The vascular system separated from the shuck as an intact unit (Fig. 5A), with the vascular strands connected by a thin layer of the parenchymatous cells of the inner zone (Fig. 5B). Globules were present on the ventral surface of the vascular system (Fig. 5B) suggesting that separation of the vascular system from the central zone was associated with cell deterioration as in shuck-shell and shuck-suture separation. Sharp indentations occurred in the area where the vascular bundles were positioned before the vascular system detached from the rest of the shuck (Fig. 5C). Only a thin, irregular layer of the inner zone remained attached to the central zone of the shuck (Fig. 5D).

Shuck-shell (Fig. 6A), shuck-vascular system (Fig. 6A), and shuck-quarter (Fig. 6B) abscission sites were evident by LM in fixed sections of shucks as darkened globules just before fruit maturity. These dense globules were scattered among cells with sparse cytoplasmic contents. Thus, every cell in the abscission layer did not deteriorate. We propose that cell deterioration results in reduced adhesion strength at abscission sites, causing separation to occur. The abscission layer extended between individual vascular strands (Fig. 6C). The vascular bundles with attendant parenchymatous cells separated as depicted by SEM (Fig. 5A) after cell wall deterioration. Cell wall deterioration and release of the globules occurred first near the dorsal surface of the inner zone (Fig. 6D). These LM studies confirmed macroscopic and SEM evaluations (Fig. 4) that abscission progressed through the inner zone from the shuck-shell juncture toward the central tissue zone. The inner tissue zone was continuous among the abscission sites, which separated the shuck from the shell, the shuck quarters, and the vascular system (Fig. 4). Superficially, there appeared to be three distinct abscission layers, because the fruit parts separated or abscised at different times. Actually, the temporal effect was due to the progressive maturation of the same abscission layer.

Environmental stresses can accelerate maturation of the preformed abscission layer resulting in premature shuck opening (Sparks et al., 1995). Accelerated shuck opening has important implications in early harvest technology and can be induced experimentally. Ethylene (Finch 1936; Kays et al., 1975) and ethephon, an ethylene-releasing compound (Hinrichs et al., 1971), have hastened shuck opening. However, neither of these compounds has been used commercially because they produced unacceptable leaf abscission and kernel darkening (Hinrichs et al., 1971; Kays et al., 1975).

Shell markings were formed by a single layer of globules deposited on, the surface of the shell (Fig. 7A). Areas without globules had a reticulate arrangement of threadlike structures with irregular boundaries without any apparent internal constituents. These threadlike structures enclosed an area with about the same diameter as the globules, suggesting the residual of cell walls. A single layer of globules was likewise on the dorsal surface of the shuck (Fig. 7B). Morphologically, the globules were the same on the two tissues (Fig. $7 \mathrm{C}$ and D). Upon separation of the shuck from the shell, the globule layer was differentially partitioned between the shuck and shell. Woodroof and Woodroof's (1927) proposal that the markings were a deposit of the separated cells of the abscission layer and that they were composed of a single layer of large thin-walled cells is only partially correct. The markings were single layered, but composed of globules and not individual cells.

An attempt was made to determine the chemical composition of the globules with histological stains for starch, protein, fat, tannin, and polyphenol (Sparks et al., 1995). However, definitive identification based on histological procedures was not possible because of the interference of the natural globule coloration with evaluation of stain uptake.

In summary, cellular events associated with pecan shuck dehiscence have been demonstrated for the first time. Shuck abscission in pecan involved a temporally regulated sequence of events with shuck-shell, then shuck-suture, and finally shuck-vascular system separation. Abscission sites shared a common tissue (the inner tissue zone) composed of a similar cell type (parenchyma) with similar morphological characteristics (globular-shaped constituents by SEM examination, darkly staining cell contents by LM investigation, and appearance of wall deterioration visible in some cells by LM). Thus, the separation in time of the abscission events did not appear to be a morphological difference in either tissue type or cellular events, but a differential maturation rate within the same tissue.

The inner tissue zone was the source of another characteristic of pecan fruit maturation, i.e., globules deposited as shell markings. Separation of the shuck from the shell resulted in a differential partitioning of these globules between the shuck and shell. The density and pattern of nut markings are cultivar specific, suggesting genetic control. The predominance of markings on the distal portion of the nut (Fig. 1B) is universal among cultivars. Thus, the inner zone of the shuck is an important tissue in pecan nut maturation, facilitating seed release and survival and providing characteristics used to identify cultivars (Sparks, 1992).

\section{Literature Cited}

Bailey, L.H. 1924. A manual of cultivated plants. Macmillan, New York. Calcote, V.R., R.E. Hunter, and T.E. Thompson. 1984. Nutrient flow through the pecan shuck into the nut and disruption of this flow by hickory shuckworm larvae. Proc. Southeastern Pecan Growers Assn. 88:61-69.

DeCandolle, C. 1862. Memoire sur lafamille des Juglandees. Annales des Sciences Nature1 Botanique 185-48.

Eichler, A.W. 1878. Bluthendiagramme. vol. 2. Leipzig.

Finch, A.H. 1936. The use of ethylene to improve pecan harvesting. Proc. Amer. Soc. Hort. Sci. 34:74-77.

Hinrichs, H.A., D.W. Ramming, and D.A. Hopfer. 1971. Effect of ethephon on thinning nuts and loosening shucks of pecan. Annu. Rpt. Northern Nut Growers Assn. 62:105-108.

Kays, S.J., T.F. Cracker, and R.E. Worley. 1975. Concentration dependencies of ethylene on shuck dehiscence and fruit and leaf abscission of Carya illinoensis (Wang.) K. Koch. Agr. Food Chem. 23:1116-1118.

Lawrence, G.H.M. 1965. Taxonomy of vascular plants. Macmillan, New York.

Manning, W.E. 1940. The morphology of the flowers of the Juglandaceae. II. The pistillate flowers and fruit. Amer. J. Bot. 27:839-852.

Nast, C.G. 1935. Morphological development of the fruit of Juglans regia. Hilgardia 9:345-381.

Shuhart, D.V. 1931. The hull and its contents. Natl. Pecan Assn. Bul. 30:119-120.

Shuhart, D.V. 1932. Morphology and anatomy of the fruit of Hicoria pecan. Bot. Gaz. 53:1-20.

Sparks, D. 1992. Pecan cultivars: The orchard's foundation. Pecan Production Innovations. Watkinsville, Ga.

Sparks, D., W. Reid, I.E. Yates, M.W. Smith, and T.G. Stevenson. 1995. Fruiting stress induces shuck decline and premature germination in pecan. J. Amer. Soc. Hort. Sci. 120:43-53.

Spurr, A.R. 1969. A low-viscosity epoxy resin embedding medium for electron microscopy. J. Ultrastruct. Res. 26:31-43.

Woodroof, J. G. and N. C. Woodroof. 1927. The development of the pecan nut (Hicoria pecan) from flower to maturity. J. Agr. Res. 34: 1049-1063. 